\title{
The Impact of Emotional Advertising on Consumer Buying Behavior for Home Appliance Products in Pakistan
}

\author{
Qaswa Kamran \\ Research Scholar, Karachi University Business School \\ University of Karachi, Pakistan \\ E-mail: QaswaKamran@hotmail.com \\ Dr. Danish Ahmed Siddiqui \\ Associate Professor, Karachi University Business School \\ University of Karachi, Pakistan \\ E-mail: daanish79@hotmail.com
}

Received: Feb. 25, 2019 Accepted: March 15, 2019 Published: April 16, 2019

doi:10.5296/bmh.v7i1.14410 URL: http://dx.doi.org/10.5296/bmh.v7i1.14410

\begin{abstract}
This study was conducted to identify the impact of emotional advertising on consumer buying behavior. The research is limited to high involvement products specifically home appliance brands. It also aims to assess the most influential advertising appeal that impacts the buying decision of the consumers. A quantitative approach was used, and the questionnaire-based survey was conducted using a sample size of 200 respondents and their response to different appeals like love, humor, happiness and excitement were recorded. The hypothesized model has been tested using factor analysis and structural equation modeling (SEM). The results show a positive impact of emotions like love, humor and happiness in influencing the purchase intention of the consumers. The paper confirms the positive relationship between emotional advertising and consumer buying behavior with respect to the home appliance brands.
\end{abstract}

Keywords: Emotional advertising, advertising appeal, consumer behavior, home appliance brands, purchase intention, high involvement products. 


\section{Introduction}

\subsection{Background to the Study}

Advertisement is a way through which marketers sell their products to their perspective customers. The basic purpose of advertisement is to inform, persuade and remind customer about a product and play a significant role to achieve the objective associated different stages of product life cycle. In old days, companies only emphasized on the functional and instrumental side of the product in their promotion. The main purpose of advertisement was to influence customers to think about the brand and to make them aware about the product features and usage. Though, the setback of these type of promotion is the point when customer understand that the only reason behind these advertisements is to communicate product, customer lose their interest and they subsequently discharge the content.

In today's modern competitive environment of business, marketers spend huge amount on advertisement to keep people aware of their brands and build strong relationship with them. Today, marketers are using different promotional gimmicks to catch people's attention and outperform their competitors to obtain a sustainable competitive advantage (Sørensen, 2008). There are different types of techniques that marketers can use in their advertisement to achieve brand objectives. Apart from these tactics, embracing emotions in advertisement has always been considered an inevitable tool to build and maintain a strong brand equity.

Different types of emotions impact people differently. From using love to humor, happiness and excitement emotions in advertisement, all these emotions have the potential to attract customer attention and engage them with the brand. It is noted that emotional advertisement has the power to stimulate people's emotion or even make them happy or sad (Rossiter \& Bellman, 2012).

Effective use of emotions in advertisement play an integral role in customer buying behavior and in achieving communication goals. So it can be established that emotions in advertisement are more important that majority of the marketers realize. Poels \& Dewitt (2006) defines emotional advertisement as a promotional technique that are designed to trigger emotional response from customer. As per Yoo and MacInnis (2005) any advertisement that endorse an emotional appeal will generate positive emotional response in customer. Emotions that are stimulated through an emotional advertisement has the ability to influence response of people towards the advertisement (Yoo \& MacInnis, 2005). The feelings provoked by the advertisement influence customer attitude and opinion towards a brand and advertisement and act as a mediator between customer and their final brand choices (Page \& Heide, 1990).

According to Lacsniak \& Muehling, (1993) traditionally, human emotions were perceived as a negative element that has no effect on consumer purchase decision. But with the passage of time a paradigm shift has been observed in the discipline of marketing and in today's business atmosphere, emotional advertisement is considered as the integral component of promotional activities. Moreover, consumer buying intention is largely relied on the sentiments of consumer (Taylor, 2005). 
Edell \& Moore, (2006) opined in their study that emotional advertisement attracts customer attention and enhance the interest in advertisement and encourage them to embrace the experience of the celebrity who endorsed it. Correspondingly, customer start relating advertisement message with themselves and the likeability and convincing power of advertisement has dramatically increased. Alvarez \& Cavanagh, (2004) described in their study that emotional advertisement put customer in a good mood and they immediately have a nice feeling about the ad. Hermeking, (2006) conclude in their study that emotional advertisement is the most memorable and create pleasant association with the brands and increase brand recognition.

Several researches have been conducted in the related domain found a significant and positive relationship between emotional advertisement and customer buying practices. Emotional advertisement enhances message comprehension, cultivate a strong a relationship with customer and increase credibility of brand choices. It provokes the intention of purchase regardless of specific product need (Samovar \& McDaniel, 2012).

Batra and Ray (1986) investigated the role of emotions in generating purchase appeal and suggest a logical association between emotional ads and customer acceptance rate. He also found that responses driven through emotional advertisement has the power to affect buying decision (Batra and Ray, 1986).

In business and academic world, many studies have been conducted to investigate the role of rational advertisement on customer buying behavior. Current study intends to analyze the impact of emotional advertisement (using emotion of love, humor, happiness and excitement in ads) on customer buying behavior. Moreover, this research contributes to build an understanding about different emotional appeals and its impact upon customer buying practices in context of home appliances products in Pakistan.

\subsection{Problem Statement}

In current competitive situation, Home Appliances brands in Pakistan is in front of the intense challenges for appealing and retention of consumer. Today's customers are encountered by abundant forms of advertisements that makes the decision process highly critical and challenging. Thus, Home Appliances brands must take significant actions for the maintenance of its competitiveness in competitive market by adopting emotional appeal in advertisement. It could be a main way for the achievement of product differentiation and for the creation of strong customer relationship by influencing customer buying decision. Home appliances being a expensive products have a rational appeal towards buying, looking at features and information. However, many products also following emotional appeal. This study would gauge their effectiveness. Also identify which sort of emotions works better in home appliances.

\subsection{Gap Analysis}

In the past various emotional appeals have been used by advertisers to analyze the change in the attitude of the consumers convincing them to buy more of the brand (Edell and Burke, 1987).The particular effect of these appeals are hard to measure (Soloman, 1992) yet 
researchers have conducted various approaches to analyze the impact of emotional advertising on consumer buying behavior. Ruth (2001) argues, it is frequent to see brands connecting emotional benefits in advertisements, allowing them to be positioned based on emotions. Positive emotions tend to influence the consumer attitudes towards advertising and the brand itself thereby generating affective responses (Batra \& Ray, 1986; Holbrook \& Batra, 1987; Ruth, 2001).

Aaker and Stayman, (1992) found that emotions can help construct the subjective and affective impressions of intangible attributes of a product. Lwin and Phau (2013) further found that when considering service sector like hotels, such emotional appeals stimulate a positive response on part of the viewers. Marketers can use emotional appeals for both utilitarian and experiential services. Ambujakshan, (2012) noted that emotional appeals can be used between product or brands with minimal differentiation. Researchers and marketers need to increase the use of emotional appeals in advertisements in order to amplify the effectiveness of the advertisements. Khanna,P. (2016) opined based on his study on teenagers that the emotions like excitement, and happiness are two prominent emotional indicators that influence the purchase of consumers as it create an impact on the viewer's mind (Khana,P 2016). Stayman 1989 focused in his study on emotions describing 855 commercials broadcasted between the years 1976 and 1986.As a conclusion his experiment showed that one third of the advertisements were perceived as to some extent informative, one third were referred as variously entertaining and around less than $2 \%$ were described as very informative.

Many a time the studies were conducted based on qualitative aspect while confining the sample size to a specific demographic which identifies a cultural barrier. The findings provide the impetus for examining emotional appeals individually in order to determine their impact on the attitude of consumers considering different brands. The past studies have been limited to analyzing the impact of emotional advertising on low involvement products since the influence of affective messages is greater compared to the high involvement products.

Different types of emotions impact people differently. However, most of the studies have not identified the dimensions of emotional advertising. The previous research on emotional domain rarely focus on its antecedents as well as consequences, yet this study aims at directing research efforts in the examination of emotional appeals, assessing the most prominent appeal that impacts the buying decision of the consumers. From using love to humor, happiness and excitement emotions in advertisement, all these emotions have the tendency to stimulate consumer attraction and engage them with the brand. The main contribution of this study is to fill in the existing gaps in the marketing literature by studying the four emotions individually like emotions of love, humor, excitement and happiness and considering their impact on consumer buying behavior.

Home Appliances brands in Pakistan is in front of the intense challenges for appealing and retention of consumer. Today's customers are encountered by abundant forms of advertisements that makes the decision process highly critical and challenging. Thus, Home Appliances brands must take significant actions for the maintenance of its competitiveness in 
competitive market by adopting emotional appeal in advertisement. It could be a main way for the achievement of product differentiation and for the creation of strong customer relationship by influencing customer buying decision. Home appliances being an expensive product category have a rational appeal towards buying, looking at features and information. However, many products also follow emotional appeal. This study would gauge their effectiveness and also identify which sort of emotions works better in home appliances. This study reveals their dominance in influencing the buying decision of consumers specifically within the category of home appliances brands among high involvement products.

\subsection{Research Objectives}

- To analyze the impact of emotional advertisement on consumer buyer behavior for Home Appliances products in Pakistan.

- To determine the effectiveness of emotional advertisement in creating strong relationship with customer (in context of Home Appliances products in Pakistan).

- To assess most influential emotional appeal in Home Appliances advertisement.

- To evaluate the degree to which emotional advertisement impact customer buying decision and repeat purchase for Home Appliances products in Pakistan.

\subsection{Research Question}

What is the impact of Emotional advertisement on customer buying behavior for Home appliance products in Pakistan?

\section{Literature Review}

Several studies have investigated the importance of emotional advertisement as a sub variable in their studies. Relevant literature for the present study, together with the scarce literature related to emotional appeals and its influence on customer buying is discussed in this chapter.

Audience perceive advertisement in two ways, a rational sense and an emotional one. That's why most of the advertisements are categorized as, i.e. thinking (logical) ads and feeling (emotional) ads (Hongxia Z., 2014).In marketing literature, a bunch of literature presents empirical evidences in favor of emotional appeals, that are responsible for effectively shaping the needs and wants of the customers influencing their purchase behavior (for example, (Holbrook, 1987); (Kotler, 2008); (Mattila, 1999); (Taute, 2011). Over the last 10-15 years researchers have identified that emotional advertisement can affect the consumer's spending manners (T. Allen, 1992), (Balidinger, 2000) and can help them to recall (Ethorson, 1990). To generate such emotions advertisers make use of expressive advertisements. emotions are perceived as a base for inducing sentimental attitudes and mainly perhaps point of advertising effectiveness (T. A. Shimp, 1981).

In modern era, using emotions in advertisement play an important role in overall success of the advertisement campaign. According to Zig Ziglar (iconic salesman and motivational speaker) "people don't purchase the brand for logical reason, they purchase the products for 
emotional reasons”. Moore, D. J., \& Harris, W. D. (1996) Defines emotional advertisement as a significant promotional tool that attract customer attention and trigger customer emotions, attitude and perception regarding a particular product or service. He also adds that emotional advertisement is easy to understand, engage people's attention and cultivate powerful memories about a brand. These memories exist in customer back of the mind, and when they undergo a buying decision these memories encourage a customer to take a final buying decision. Even these emotional advertisements have the ability to motivate customer to buy an expensive or unneeded product. Marketers are now using emotions extensively in advertisement in order to make more sales on the basis of emotions.

Shahid, M. \& Bilal, A (2016) Also proposed that emotional advertisement help customer to associate their emotions and feelings with a particular product. It has the power to make people happy or sad. Every ad produces an affectionate response as naturally everything we face in our daily life generates an impulsive emotional reaction. Duncan, C. P., \& Nelson, J.E. (1985).Emphasized that marketers should need to understand the indispensable importance of using emotion in advertisement. Customer emotional reactions are connected to their past experiences. These familiarities consequently will impact customer response to buying decision. Advertisement showing life events and engaging and connecting people put customers in a good mood and stay longer in memories. When people see advertisement with emotional cues, they try to relate them with something familiar in their lives.

Eckler, P., \& Bolls, P. (2011) founded that promotional content with emotional appeals aimed mainly to influence people social, psychological and physiological needs. Emotional cues may nurture a variety of feelings ranging from love, happiness, excitement, humor to fear. Emotional advertisement helps to create a strong relationship with customer and enhance brand loyalty. Marketers want their customers to experience a feel association and an emotional bond with the brand. Emotional appeals directly hit the right hemisphere of the brain which is responsible to control the left side and related to the memory and creativity of mind. Visual and advertisement background are more important in emotional appeal, creating a synergy between all these elements can actually enhance the persuasiveness of communication. Employing more than one emotion in communication influence people's senses and create happy customers.

William, P. (2000) Investigated in his study that how brands employ a variety of emotions in advertisement to enhance their persuasiveness. Human nature strongly experiences different types of emotions, ranging between love, happiness, humor, excitement, sad, fear and angry. In our research we primarily focused on the role of love, humor, happiness and excitement appeal in emotional advertisement.

- Emotion of Happiness: Marketers want their customer to relate their brands with pleasant moments, smiles and happiness. Companies that focus on executing happy life and connecting and engaging people create loyal customer. According to a research conducted by Ambler, T., \& Burne, T. (1999) advertisement with happiness appeal are shared frequently and have maximum number of conversions.

- Emotion of Love: Love appeal is one of the most commonly used emotional technique 
in advertisement that companies use to influence customer to buy their products. Love appeal works well when the perceived value and quality of a brand you are advertising is extremely high. Khana, P. (2016) found in their study that love appeal in that focuses on a strong relationship between people, showing perfection and enhancement of their emotional bond will likely to influence people buying decision. Khana, P. (2016) Also suggest that Love appeal is not all showing couples and relationship between two people, but it is concerned with nurturing strong feelings that is heartening and admired.

- Emotion of Humor: Humor is a definite part of human nature. According to Weinberger and Gullas (1992) humorous advertisement has the ability to strongly attract audience attention and create interest in advertisement which in turn has increased the interest for a product. A study conducted by Speck (1987) compares the impact of humorous advertisement with the non- humor advertisement. The results reveal that in first stage it attracts people attention, induce them to sustain interest, make them to easily get the message content and in the last encourage them to take final action of purchase. In a competitive marketing environment, it helps the brand to break through the traditional advertisement clutter and give them a refreshing and relaxing feeling. He concluded in his research that humorous advertisement perform far better than non-humorous advertisement in terms of creating awareness and preferences.

- Emotion of Excitement/Fun: Excitement/ fun appeal is primarily useful for creating brand recognition and brand recall for a particular product or service. Brands employing excitement or fun appeal in advertisement encourage people to buy the brand to feel something unique and stirring. This same emotional appeal used by marketers to highlight their brand functions and enhance message comprehension (Khana, P, 2016).

Emotions exclusively contribute in creating an attitude towards the advertisement, influencing the attribute-oriented beliefs of the brand, and shaping the attitude towards the brand in general. Batra and Ray (1986) in their study provided empirical evidences and suggested a correlation between affective response of the individuals, its impact on the attitude towards the advertisement, attitude towards the brand and finally the purchase decision of the people. They confirmed in their study the importance of using emotions in advertisements since it contributes in the effectiveness of the advertisements.

Niazi, G., Siddiqui, J., Alishah, (2012) Proposed in his study that there is significant relationship between emotional advertisement and people buying decision. Due to increasing exposure, people are now become more responsive to the emotional cues rather than rational appeal. Emotional advertisement helps to memorize the brand and leads to direct purchase and repurchase. According to emotional factor in advertisement grab customer attention, arouse interest, create desire and motivate them to take final purchase decision.

William, P. (2000) Analyzed in their study that customer brand preferences, brand recognition, brand recall, brand preferences finally purchase decision depends on the type emotion used in advertisement. Marketers use advertisement to promote its brands and emotions in advertisement can create positive and negative brand image in the minds of customer. 


\section{I Macrothink}

Business and Management Horizons

ISSN 2326-0297

2019, Vol. 7, No. 1

The main focus of this study is to assess the significance of emotional advertisement on customer buying behavior for Home appliances products in Pakistan. The influence of rational and emotional advertisement varies from customer to customer, so it's imperative to identify the most effective emotional appeals that can affect customer buying practices for high involvement products.

\subsection{Conceptual Framework of the Study}

On the basis of literature review, conceptual framework is developed which shows the relationship between predicted variables and one response variable. The framework has generated the ground work for the study and consist of four emotional advertisement sub dimensions along with one dependent variable which is customer buying behavior.

- Emotion of Happiness: Marketers want their customer to relate their brands with pleasant moments, smiles and happiness. Companies that focus on executing happy life and connecting and engaging people create loyal customer. According to a research conducted by Ambler, T., \& Burne, T. (1999) advertisement with happiness appeal are shared frequently and have maximum number of conversions.

- Emotion of Love: Love appeal is one of the most commonly used emotional technique in advertisement that companies use to influence customer to buy their products. Khanna,P. (2016) opined the use of emotions like love depicting on a strong relationship between people, which enhances the emotional bond and is likely to encourage consumer's buying decision. Khana, P. (2016) also suggested that Love appeal is not all showing couples and relationship between two people, but it is concerned with nurturing strong feelings that is heartening and admired.

- Emotion of Humor: Humor is a definite part of human nature. According to Weinberger and Gullas (1992) emotions of humor used in an advertisement has a strong impact on viewers driving their interest towards the ad and ultimately the purchase decision. A study conducted by Speck (1987) comparing humorous and non-humorous ads revealed that humor attracts people's attention, induce them to sustain interest, make them to easily get the message content and in the last encourage them to take final action of purchase.

- Emotion of Excitement/Fun: Excitement/ fun appeal is primarily useful for creating brand recognition and brand recall for a particular product or service. Brands employing excitement or fun appeal in advertisement encourage people to buy the brand to feel something unique and stirring. This same emotional appeal used by marketers to highlight their brand functions and enhance message comprehension (Khana, P, 2016). 


\section{1ll Macrothink}

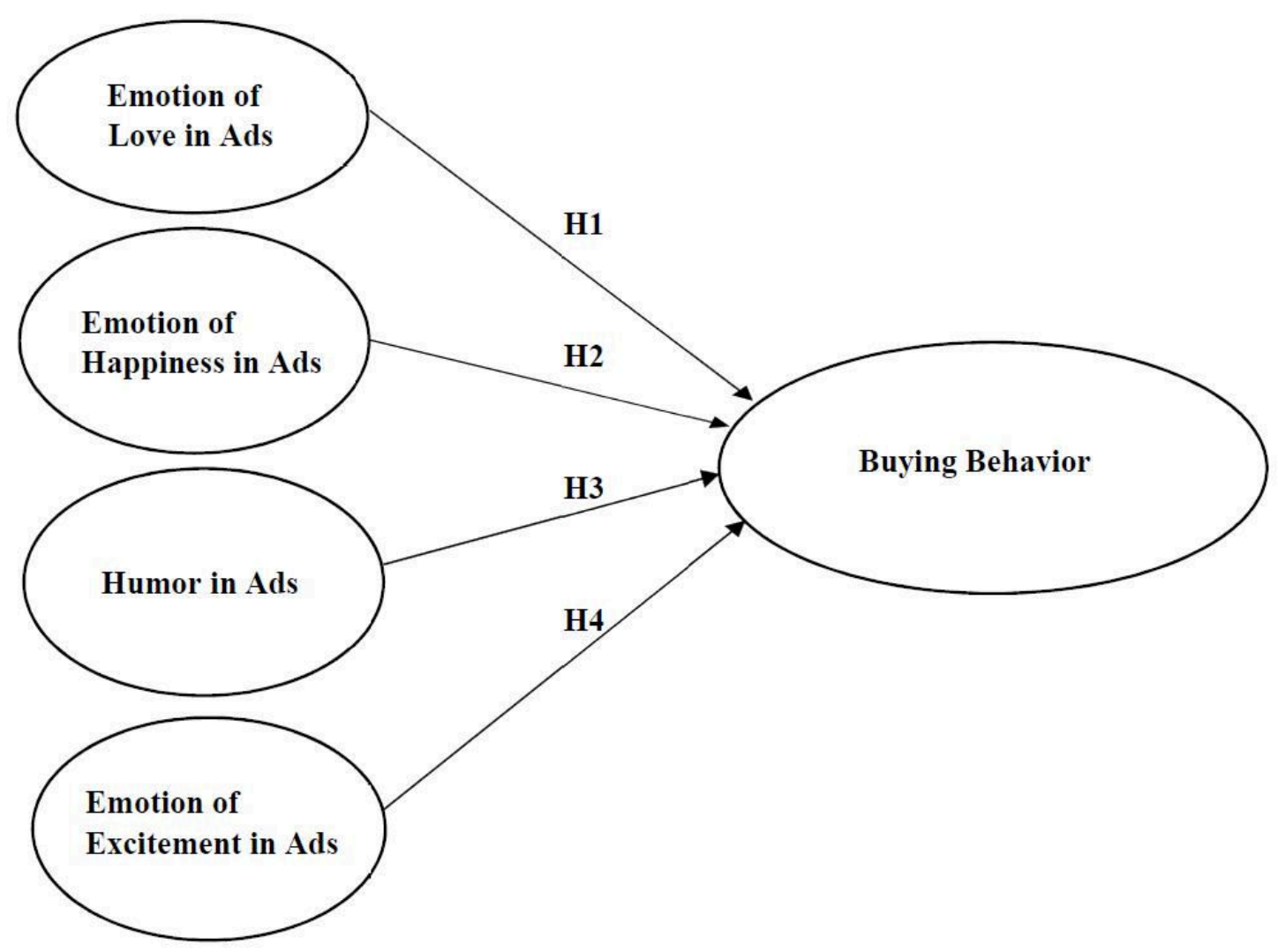

Figure 1. Emotional Advertisement

\subsection{Research Hypotheses}

\section{NULL HYPOTHESIS}

Emotional Advertisement including Emotion of Love, Humor, Happiness and Excitement has no impact on buying behavior of customer with respect to home appliances products in Pakistan.

$\beta 1=\beta 2=\beta 3=\beta 4=0$

\section{ALTERNATIVE HYPOTHESES}

Hypothesis 1: Emotion of Love in advertisement is positively associated with customer buying behavior for Home appliances products in Pakistan $\left(\beta_{1} \neq 0\right)$.

Hypothesis 2: Emotion of Humor in Advertisement is positively associated with customer buying behavior for Home appliances products in Pakistan $\left(\beta_{2} \neq 0\right)$

Hypothesis 3: Emotion of Happiness in advertisement is positively associated with customer buying for Home appliances products in Pakistan behavior $\left(\beta_{3} \neq 0\right)$

Hypothesis 4: Emotion of Excitement in advertisement is positively associated with customer buying behavior for Home appliances products in Pakistan $\left(\beta_{4} \neq 0\right)$. 


\section{Data Collection}

Convenience sampling method is used to collect the data. The questionnaire survey is conducted both online and offline. Questionnaires were directly given to the respondents at: offices, universities, malls etc. Additionally, online questionnaire was shared via a link with respondents through email and facebook to reach a sample size of 200 respondents.

\subsection{Questionnaire Design}

A quantitative approach is used to identify the impact of emotional advertising on consumer purchase intention. This means that research is based on questionnaire survey applied on a sample selected from target population. On the questionnaire, closed ended questions were asked from the respondents to examine their demographic profile and a Likert scale is used to record their responses on emotional advertising. The Likert scale is based on five points where 1 indicates strongly disagree and 5 is strongly agree. Since the study is focused on the category of home appliances hence another question "how often they purchase home appliance products" is asked specifically to assess the buying pattern of the respondents relating to that category.

\section{Data Analysis and Discussion}

\subsection{Demographic Profile}

Table 1 shows sample population demographic information in terms of gender, age, qualification and occupation variables. As it is hardly possible to construct a complete sample frame for such a huge and dispersed population, thus we employed convenience sampling approach.

Table 1. Respondents Demographic Profiling

\begin{tabular}{llll}
\hline Variable & Category & Frequency & Percentage \\
\hline Gender & Male & 132 & $66 \%$ \\
& Female & 68 & $34 \%$ \\
\hline Age & $25-35$ & 48 & $24 \%$ \\
& $35-40$ & 77 & $38.5 \%$ \\
& $40-45$ & 42 & $21 \%$ \\
& $45 \&$ above & 33 & $16.5 \%$ \\
\hline Qualification & Matric/O-Levels & 13 & $6.5 \%$ \\
& Intermediate/A-levels & 60 & $30 \%$ \\
& Graduate & 62 & $31 \%$ \\
\hline Occupation & Masters & 65 & $32.5 \%$ \\
& Student & 33 & $16.5 \%$ \\
& Employed & 132 & $66 \%$ \\
& Home Maker & 29 & $14.5 \%$ \\
\hline Frequency of Purchase of & Yetired & 6 & $3 \%$ \\
Apme & After 2-3 Years & 18 & $9 \%$ \\
& 5 years & 53 & $26.5 \%$ \\
\hline
\end{tabular}




\section{Al Macrothink}

Business and Management Horizons

ISSN 2326-0297

2019, Vol. 7, No. 1

From 200 respondents $66 \%$ were male and $34 \%$ respondents were female. According to the results, 77 of the participants between 35-40 years of age dominates the sample and remained significant for the study results. Looking at the Qualification variable, the data shows $30 \%$ of the participants were Intermediate/Alevels, 31\% were Graduate and 32.5\% of the respondents were holding master's degree. Furthermore $66 \%$ of the sample participants were employed and shows maximum share of the results where $16.5 \%$ of the respondents were students. For majority of respondents he frequency of purchasing home appliances products were 9\% yearly ,26.5\% prefer to buy after $2-3$ years, $25 \%$ would make the decision after 5 years and $39.5 \%$ would hardly switch unless they find a major damage. On the basis of demographic profiling of respondents, it is clear that our study is based on the actual population who have been buying different home appliances products for their personal use.

\subsection{Descriptive Statistics}

Table 2. Descriptive Statistics (Individual)

\begin{tabular}{|c|c|c|c|c|}
\hline Emotion of Love & $\begin{array}{l}\text { Mean } \\
\text { Statistic }\end{array}$ & Std. Error & $\begin{array}{l}\text { Std. Deviation } \\
\text { Statistic }\end{array}$ & $\begin{array}{l}\text { Variance } \\
\text { Statistic }\end{array}$ \\
\hline $\begin{array}{l}\text { Home Appliances Advertisement showing love and relationships put me } \\
\text { in a good mood and I immediately have a nice feeling about ad. }\end{array}$ & 3.3300 & .07704 & 1.08951 & 1.187 \\
\hline $\begin{array}{l}\text { Love appeal in advertisement enhance liking of Home appliances } \\
\text { products. }\end{array}$ & 3.5550 & .06168 & .87223 & .761 \\
\hline $\begin{array}{l}\text { Ads with love emotion are the most memorable and create pleasant } \\
\text { association with the Home Appliances brands. }\end{array}$ & 3.1800 & .06901 & .97589 & .952 \\
\hline $\begin{array}{l}\text { I remember and retain the information contained in ads with love appeal } \\
\text { for a long time }\end{array}$ & 3.1700 & .07704 & 1.08951 & 1.187 \\
\hline
\end{tabular}

Emotions of Love portray how the advertisements using the emotional appeal enhance relationship with viewers and help them memorize the brand name by forming an association between the brand and consumers. The images show couples or relationship between people, by cultivating strong feelings that is admired by the viewers. The above table demonstrate mean, standard deviation and variance of 200 respondents for each item used in the love appeal. The results show that for each item the values lie between range of $3.1-3.5$ showing a neutral to agreed response for the items used. The calculated values of standard deviation and variances also prove that love appeal in emotional advertisement are very effective as it indicates smaller distance from the mean.

\begin{tabular}{lllll}
\hline Emotion of Humor & $\begin{array}{l}\text { Mean } \\
\text { Statistic }\end{array}$ & Std. Error & $\begin{array}{l}\text { Std. Deviation } \\
\text { Statistic }\end{array}$ & $\begin{array}{l}\text { Variance } \\
\text { Statistic }\end{array}$ \\
\hline $\begin{array}{l}\text { I strongly recommend people buy Home Appliances from the brands of } \\
\text { humorous ads. }\end{array}$ & 3.9350 & .07505 & 1.06132 & 1.126 \\
\hline $\begin{array}{l}\text { The Humorous ads made me recognize among competing brands. } \\
\text { Home Appliances Brands with Humorous Ads helps me to recall its } \\
\text { brand before shopping. }\end{array}$ & 3.2600 & .07643 & 1.08085 & 1.168 \\
\hline $\begin{array}{l}\text { I discuss the variety of products offered by the Home Appliances Brands } \\
\text { of Humorous ads. }\end{array}$ & .06281 & .88828 & .789 \\
\hline
\end{tabular}


Emotions of Humor has the tendency to enhance brand preference and using the emotional appeal increases chances of retaining the brand and recall at the point of purchase. It creates brand awareness by attracting the audience's attention and keeping the brand at the top of mind. The funny images or dialogues engage the viewers with the commercial. The table shows mean value for each item between a range of $3.1-3.9$ which illustrates participants agreeableness for humor advertisement. In addition to this, the values of standard deviation and variance are quite low which ensures positive impact of humor on buying decision of customer.

\begin{tabular}{lcccc}
\hline Emotion of Happiness & $\begin{array}{l}\text { Mean } \\
\text { Statistic }\end{array}$ & Std. Error & $\begin{array}{l}\text { Std. Deviation } \\
\text { Statistic }\end{array}$ & $\begin{array}{l}\text { Variance } \\
\text { Statistic }\end{array}$ \\
\hline $\begin{array}{l}\text { Home appliances Ads focuses on happy images of the people appeals to } \\
\text { my senses. }\end{array}$ & 3.2900 & .07110 & 1.00546 & 1.011 \\
\hline $\begin{array}{l}\text { Home Appliances ads showing connecting and engaging people gives } \\
\text { me a positive feeling about the brand. }\end{array}$ & 3.4650 & .07363 & 1.04125 & 1.084 \\
\hline $\begin{array}{l}\text { Home Appliances Ads that expresses a tone of joy and happy moments } \\
\text { creates happy customers. }\end{array}$ & 3.0950 & .07849 & 1.11002 & 1.232 \\
\hline I can easily relate happy memories with Home Appliances ads. & 3.6600 & .07812 & 1.10476 & 1.221 \\
\hline
\end{tabular}

Emotion of Happiness depict a happy life connecting people and help create loyal customers. Such emotions display a perfect theme that touches the heart of its consumers nurturing happy responses. When frequently used this emotion helps in maximum number of conversions. The table shows mean value for each item lying within a range of 3.0 - 3.6 showing the neutral to agreed response of the sample data and a lower standard deviation and variance further confirming the response.

\begin{tabular}{lllcc}
\hline Emotion of Excitement & $\begin{array}{l}\text { Mean } \\
\text { Statistic }\end{array}$ & Std. Error & $\begin{array}{l}\text { Std. Deviation } \\
\text { Statistic }\end{array}$ & $\begin{array}{l}\text { Variance } \\
\text { Statistic }\end{array}$ \\
\hline Home Appliances Ads designed to entertain and grab attention. & 3.4350 & .06363 & .89990 & .810 \\
\hline $\begin{array}{l}\text { Home Appliances advertisements with excitement appeal enhance } \\
\text { message comprehension. }\end{array}$ & 3.5200 & .06299 & .89082 & .794 \\
\hline $\begin{array}{l}\text { I usually look for Ads that trigger feelings of excitement in me. } \\
\text { Excitement Appeals are better at achieving communication Goals. }\end{array}$ & 3.4950 & .07053 & .99747 & .995 \\
\hline
\end{tabular}

Emotions of Excitement triggers feelings of entertainment in the viewers grabbing their attention and enhancing message comprehension. The images have the tendency to excite the consumers about the commercial persuading them to know more about the brand. The mean value in the table lies within the range of $3.4-3.5$ respectively, illustrating neutral to agreed responses of the sample respondents for each item. 


\begin{tabular}{|c|c|c|c|c|}
\hline Buying Behavior & $\begin{array}{l}\text { Mean } \\
\text { Statistic }\end{array}$ & Std. Error & $\begin{array}{l}\text { Std. Deviation } \\
\text { Statistic }\end{array}$ & $\begin{array}{l}\text { Variance } \\
\text { Statistic }\end{array}$ \\
\hline $\begin{array}{l}\text { I expect to purchase or repurchase Home appliance brands using } \\
\text { emotional appeal in advertisement. }\end{array}$ & 3.9100 & .06504 & .91985 & .846 \\
\hline Purchasing Home Appliance Brand with Emotional ad is rewarding. & 3.5400 & .07154 & 1.01169 & 1.024 \\
\hline $\begin{array}{l}\text { The Probability that I would consider buying Home Appliance from } \\
\text { Brands using emotional appeal is high. }\end{array}$ & 3.3900 & .06411 & .90665 & .822 \\
\hline $\begin{array}{l}\text { I prefer to buy certain Home Appliance Brands over others because of } \\
\text { their emotional advertisement. }\end{array}$ & 3.4500 & .06409 & .90643 & .822 \\
\hline Emotional Advertisement of Home Appliance affect my buying decision. & 3.6600 & .06475 & .91575 & .839 \\
\hline
\end{tabular}

The variable shows the impact of the emotions of love, happiness, humor and excitement on the consumer's buying intention. The greater the impact of emotional appeal on viewer's mind the greater the probability of purchasing or repurchasing a brand or product displayed in the commercial. The above table shows the mean of Buying Behavior which is the dependent variable of the study lying within the range of $3.3-3.9$ for each item which indicates that majority of the respondents agreed upon emotional advertisement's favorable influence on buying behavior with the low standard deviation.

Table 3. Descriptive Statistics (Factors)

\begin{tabular}{lllll}
\hline & Mean & Std. Error & Std. Deviation & Variance \\
\hline Love & 3.3088 & .05182 & .73283 & .537 \\
Humor & 3.1838 & .05202 & .73561 & .541 \\
Happiness & 3.1475 & .05026 & .71074 & .505 \\
Excitement & 3.5012 & .04800 & .67878 & .461 \\
Buying Behavior & 3.5900 & .05032 & .71164 & .506 \\
\hline
\end{tabular}

Table 3 shows descriptive statistics of the sample data including $\mathrm{N}=$ size of data, Range= minimum and maximum data values along with Mean, Standard Deviation and Variances of all sample values. The above table demonstrate mean, standard deviation and variance of 200 respondents. Advertisement using love appeal have mean value of 3.308 which falls between neutral to agree range, the calculated values of standard deviation and variances are 0.732 and 0.537 respectively which shows that love appeal in emotional advertisement are very effective as it indicates smaller distance from the mean. Mean value for the emotion of Humor in advertisement is 3.183 which again shows participants agreeableness for humorous advertisement. Besides the value Standard deviation and variance are 0.735 and 0.541 respectively which endorse the positive impact of humor on buying decision of customer. Looking at the emotion of happiness, results shows 3.147 mean value with 0.710 standard deviation and 0.505 variation in sample data. Emotion of excitement in home appliance advertisement again positively affect customer buying with 3.501 mean and 0.461 variance results. In addition, the mean of Buying Behavior which is the dependent variable of the 
study is 3.59 which indicates that majority of the respondents agreed upon emotional advertisement positive influence on buying behavior with the low standard deviation 0.711 .

\subsection{Inferential Statistics}

To measure the impact of Emotional advertisement on buying behavior of customer with context of home appliance products, a research instrument having 21 items was used through which an exploratory analysis was conducted. Inferential statistics helps to make inferences and conclusive evidence from the sample data drawn from a population (Gillet, Fouquereau, Forest, Brunault, \& Colombat, 2012; Inoue, Kawakami, Tsuno, Tomioka, \& Nakanishi, 2012; Rita Silva \& Caetano, 2014). Exploratory Factor analysis with the help of SPSS is used to reduce large number of variables to the most important ones (Büyüköztürk, 2007; Tavşanc1l, 2002). Results from the remaining items produced a reliable model and considered for reliability and validity test and path analysis.

4.3.1 Reliability Analysis

Table 4. Reliability Scores (N=200)

\begin{tabular}{ll}
\hline & Cronbach alpha \\
\hline Emotion of Love in Ads (IV) & 0.7 \\
Emotion of Humor in Ads (IV) & 0.7 \\
Emotion of Happiness in Ads (IV) & 0.6 \\
Emotion of Excitement in Ads (IV) & 0.7 \\
Buying Behavior (DV) & 0.8 \\
\hline
\end{tabular}

Reliability test was done to assess the significance of data (J. Nunnally, 1978; J. C. Nunnally $\&$ Bernstein, 1994). In above table the values of reliability test show acceptable results with all items included. The value of Cronbach alpha for emotion of love in advertisement is 0.7 . The reliability of all the variables including dependent and independent variables is greater than the cut off value that is 0.70 which was good (Santos, 1999). Overall Cronbach's Alpha of the questionnaire was 0.889 . Which is significant as it is greater than the cut off value which is 0.7 . Besides buying behaviour indicates 0.8 reliability which is also acceptable as it falls between the standard ranges of 0.5-0.9. Research instrument used in this study measure different aspects of Emotional Advertisement as love, humor, happiness and excitement appeal which may Home appliance brands in influencing customer buying behavior.

\subsubsection{Exploratory Factor Analysis}

Factor analysis was employed to reduce large number of variables to extract most underlying variables called factor. Exploratory factor analysis is a useful method to examine the variability among observed variables and excerpt variability from items and load them into a common factor (Terre Blanche \& Durrheim, 1999). As the study entails exploratory nature, factor analysis was done to identify the most important construct, i.e. Emotion of Love, Humor, Happiness, Excitement and buying behavior. After the reduction of items the 
instrument was reduced to 20 items with 4 items for each factor. Before item reductions, the instrument consisted of 21 items. Buying Behavior comprised of 5 items but only 4 items originally load on its factor. While emotion of love, humor, and happiness in advertisement were endured consistent with all original 4 statement loaded on its factor. As the study entails exploratory nature, factor analysis was done to identify the most important construct, i.e. Emotion of Love, Humor, Happiness, Excitement and buying behavior. The value of 'Kaiser-Meyer-Olkin which is the statistical Measure of Sampling

Adequacy' (KMO) should be greater than 0.7 (Tabachnick \& Fidell, 2001) and resultant value 0.878 shows that factor analysis has produced valuable information of the extracted construct besides the "Bartlett's Test of Sphericity" indicates significant value (i.e. 0.000) and confirms reliable results of factor analysis.

Table 5. KMO and Bartlett's Test

\begin{tabular}{|c|c|c|c|c|}
\hline \multicolumn{4}{|c|}{ Kaiser-Meyer-Olkin Measure of Sampling Adequacy. } & \multirow{2}{*}{$\frac{.878}{132.6}$} \\
\hline \multirow{3}{*}{$\begin{array}{l}\text { Bartlett's } \\
\text { Sphericity }\end{array}$} & \multirow{3}{*}{ Test } & \multirow{3}{*}{ of } & Approx. Chi-Square & \\
\hline & & & Df & 210 \\
\hline & & & Sig. & .000 \\
\hline
\end{tabular}

Table 6. Rotated Component Matrix

\begin{tabular}{|c|c|c|c|}
\hline Latent Variable & Item Label & Item Description & $\begin{array}{l}\text { Standardized Factor } \\
\text { Loading }\end{array}$ \\
\hline \multirow{4}{*}{$\begin{array}{l}\text { Emotion of Love in } \\
\text { Ads }\end{array}$} & EL1 & Attracts attention & 0.73 \\
\hline & EL2 & Induce Nice Feelings & 0.72 \\
\hline & EL3 & Enhance Liking & 0.67 \\
\hline & EL4 & Create Association & 0.74 \\
\hline \multirow{4}{*}{$\begin{array}{l}\text { Emotion of Humor } \\
\text { in Ads }\end{array}$} & EH1 & Increase Recommendation & 0.55 \\
\hline & $\mathrm{EH} 2$ & Recognize Competing Brands & 0.57 \\
\hline & $\mathrm{EH} 3$ & Increase Recall & 0.60 \\
\hline & EH4 & Create Loyalty & 0.66 \\
\hline \multirow{4}{*}{$\begin{array}{l}\text { Emotion of } \\
\text { Happiness in Ads }\end{array}$} & EHAP1 & Induce Positivity towards products & 0.61 \\
\hline & EHAP2 & Create Happy Customer & 0.61 \\
\hline & EHAP3 & Induce to purchase & 0.68 \\
\hline & EHAP4 & Help to Build Memories with Brands & 0.74 \\
\hline \multirow{4}{*}{$\begin{array}{l}\text { Emotion of } \\
\text { Excitement in Ads }\end{array}$} & EE1 & Entertain & 0.71 \\
\hline & EE2 & Enhance Message Comprehension & 0.73 \\
\hline & EE3 & Trigger Excitement & 0.68 \\
\hline & EE4 & Achieve Communication Goals & 0.70 \\
\hline \multirow[t]{5}{*}{ Buying Behavior } & $\mathrm{BB} 1$ & Affect Buying Decision & 0.55 \\
\hline & BB2 & Preference Over others & 0.72 \\
\hline & BB3 & Increase Consideration for Purchase & 0.57 \\
\hline & BB4 & Cultivate rewarding shopping experience & 0.47 \\
\hline & BB5 & Repurchase & 0.17 \\
\hline
\end{tabular}

The above table shows Standardized factor loading for each item and shows the association 


\section{Macrothink}

between individual items with the extract construct. Factor loading for each item depicts reasonable to strong relationship with the underlying construct. (I.e. a greater value than 0.4 for each factor loading).

\subsubsection{Confirmatory Factor Analysis Using Amos}

Confirmatory factor analysis was performed using AMOS. Factor analysis was employed to reduce large number of variables to extract most underlying variables called factor. Confirmatory factor analysis is a useful method to examine the variability among observed variables and excerpt variability from items and load them into a common factor. As the study entails exploratory nature, factor analysis was done to identify the most important construct, i.e. Emotion of Love, Humor, Happiness, Excitement and buying behavior.

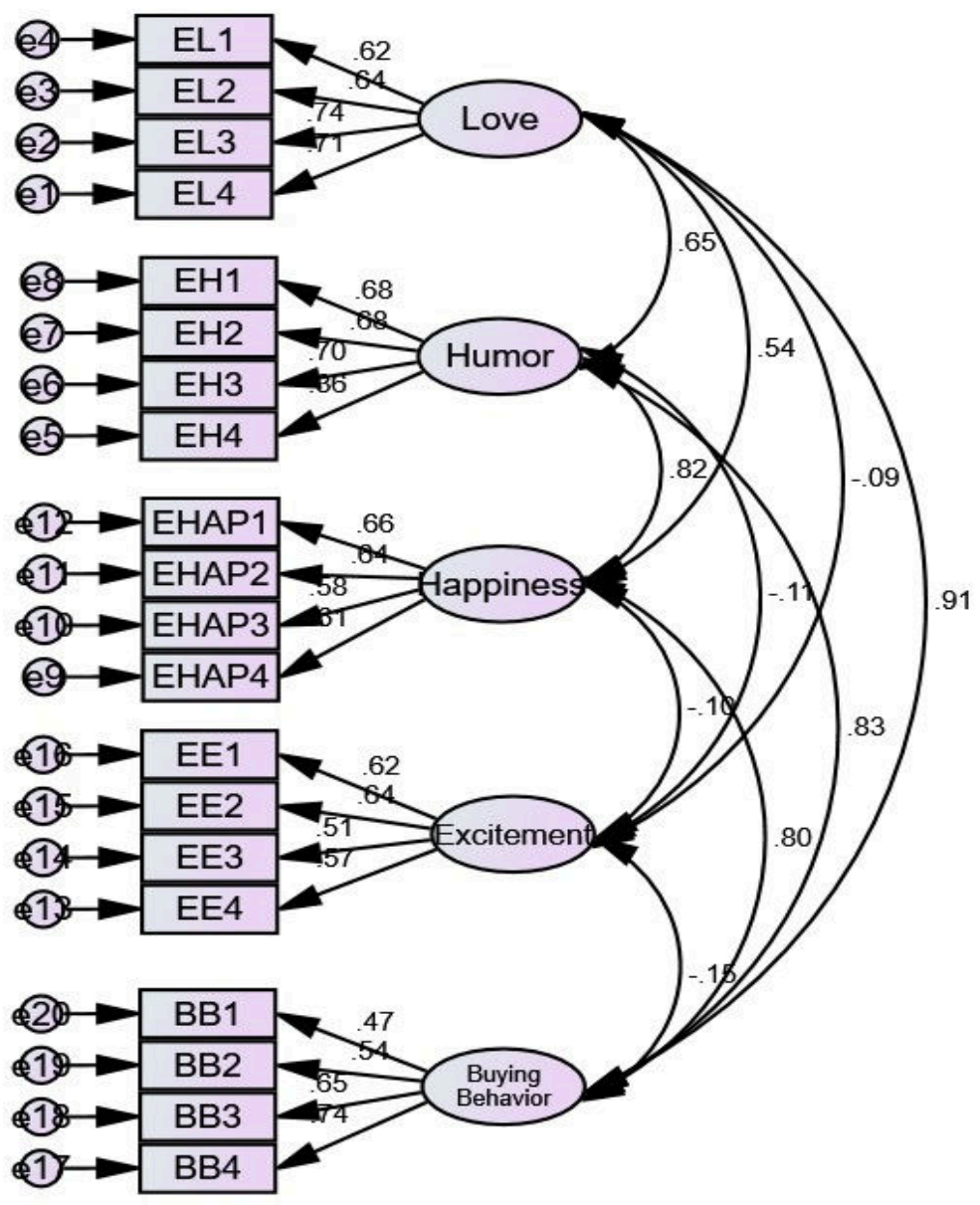

Figure 2. Confirmatory Factor Analysis Using Amos 
Table 7. Standardized Regression Weights

\begin{tabular}{llll}
\hline Latent Variable & Item Label & Item Description & $\begin{array}{l}\text { Standardized Factor } \\
\text { Loading }\end{array}$ \\
\hline Emotion of Love in & EL1 & Attracts attention & 0.62 \\
Ads & EL2 & Induce Nice Feelings & 0.64 \\
& EL3 & Enhance Liking & 0.74 \\
& EL4 & Create Association & 0.71 \\
\hline Emotion of Humor & EH1 & Increase Recommendation & 0.68 \\
in Ads & EH2 & Recognize Competing Brands & 0.68 \\
& EH3 & Increase Recall & 0.70 \\
& EH4 & Create Loyalty & 0.86 \\
\hline Emotion of & EHAP1 & Induce Positivity towards products & 0.66 \\
Happiness in Ads & EHAP2 & Create Happy Customer & 0.64 \\
& EHAP3 & Induce to purchase & 0.58 \\
& EHAP4 & Help to Build Memories With Brands & 0.81 \\
\hline Emotion of & EE1 & Entertain & 0.62 \\
Excitement in Ads & EE2 & Enhance Message Comprehension & 0.64 \\
& EE3 & Trigger Excitement & 0.51 \\
& EE4 & Achieve Communication Goals & 0.57 \\
\hline Buying Behavior & BB1 & Affect Buying Decision & 0.47 \\
& BB2 & Preference Over others & 0.54 \\
& BB3 & Increase Consideration for Purchase & 0.65 \\
& BB4 & Cultivate rewarding shopping experience & 0.74 \\
\hline
\end{tabular}

The above table shows Standardized factor loading for each item and shows the association between individual items with the extract construct. Factor loading for each item depicts reasonable to strong relationship with the underlying construct.

\subsubsection{Evaluating Measurement Model Fitness}

To evaluate the fitness of the proposed model, Amos delivers a set of useful indices that are used to determine the fitness and validity of the hypothesized model. Out of different significant indices, root mean square error of approximation (RMSEA), goodness of fit index (GFI), Chi-Square, CMIN/DF, adjusted goodness of fit index (AGFI), and comparative fit indices were observed to determine the authenticity of the research model. The discussed indices shows the degree to which constructs are related to one another. Table 8 and figure 2 demonstrate the resultant values.

Table 8. Model Fitness Test

\begin{tabular}{lll}
\hline Model Fit & Resultant Value & Threshold \\
\hline CMIN/DF & 1.317 & $<3$ good $;<$ Acceptable \\
CFI & 0.953 & Closer to $1 ;$ good \\
GFI & 0.908 & $>0.90$ \\
AGFI & 0.879 & $>0.90$ \\
RMR & 0.055 & $<0.08$ \\
RMSEA & 0.040 & $<0.08$ \\
PCLOSE & 0.87 & $>0.05$ \\
\hline
\end{tabular}


The measured values of CMIN/DF, CFI, PCLOSE GFI, RMR, and RMSEA meet the threshold and shows an acceptable model fit. However the values of AGFI slightly differs from the standard values.

\subsubsection{Structural Equation Modeling}

Structural equation modeling used to evaluate the structural relationship between exogenous and endogenous variables. The structural equation modeling includes factor analysis and multivariate analysis of the model. Firstly we evaluate the model fitness and measure whether the paths showing the relationship between measured and latent variables are significant or not. The path diagram showed in figure 3. In this diagram emotion of love, humor, happiness and excitement draws towards customer buying behavior. Besides table 9 shows the model fit results by analyzing model fit indices.

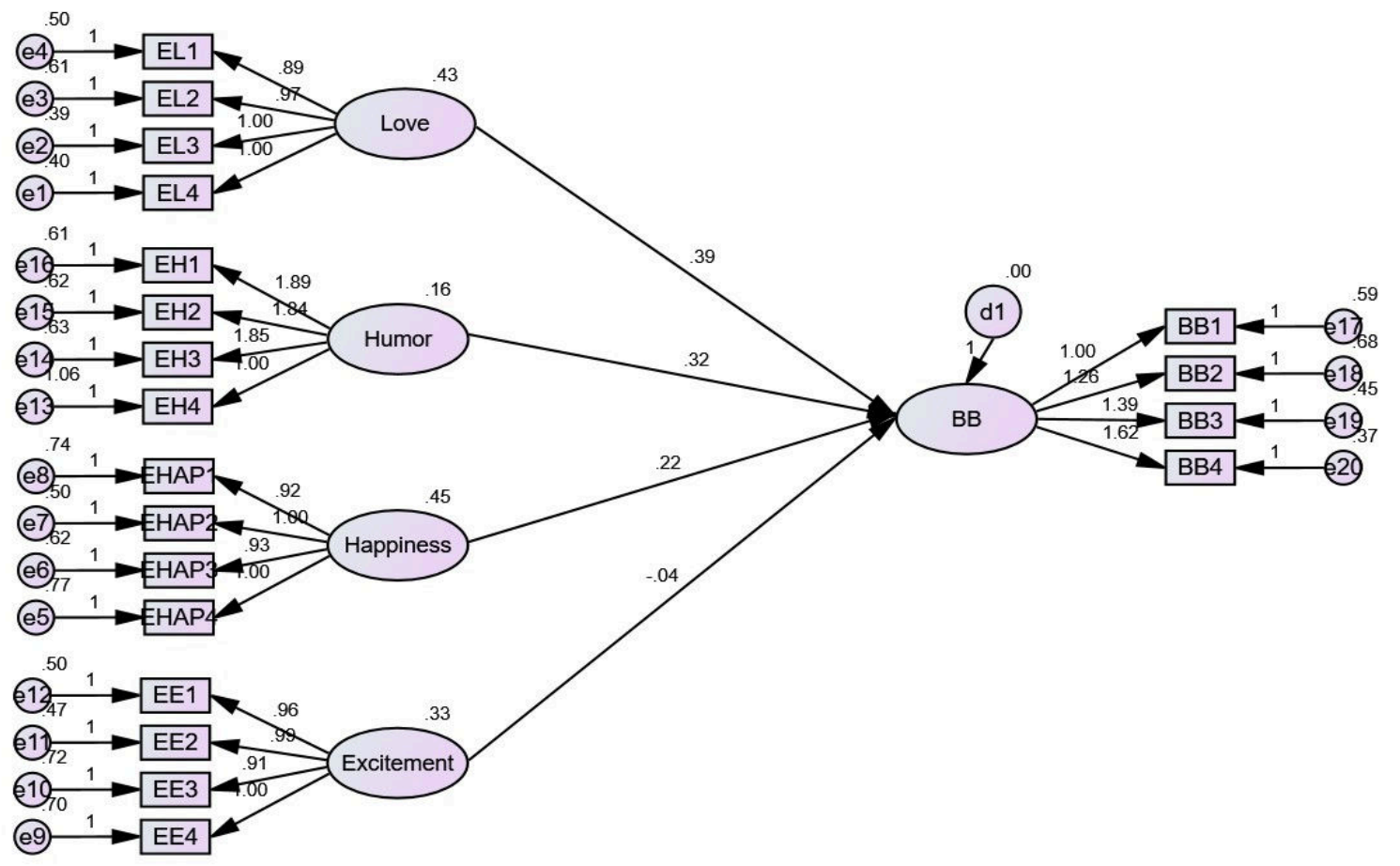

Figure 3. Path Diagram

\subsubsection{Evaluating Measurement Model Fitness}

To evaluate the fitness of the proposed model, Amos delivers a set of useful indices that are used to determine the fitness and validity of the hypothesized model. Out of different significant indices, root mean square error of approximation (RMSEA), goodness of fit index 
(GFI), Chi-Square, CMIN/DF, adjusted goodness of fit index (AGFI), and comparative fit indices were observed to determine the authenticity of the research model. The discussed indices shows the degree to which constructs are related to one another. Table 9 and figure 3 demonstrate the resultant values.

Table 9. Model Fitness Test

\begin{tabular}{lll}
\hline Model Fit & Resultant Value & Threshold \\
\hline CMIN/DF & 2.152 & $<3$ good ; 5 Acceptable \\
CFI & 0.82 & Closer to $1 ;$ good \\
GFI & 0.85 & $>0.90$ \\
AGFI & 0.81 & $>0.90$ \\
RMR & 0.17 & $<0.08$ \\
RMSEA & 0.073 & $<0.08$ \\
PCLOSE & 0.00 & $>0.05$ \\
\hline
\end{tabular}

There are different parameters to evaluate the goodness of a fit model. The study has adopted seven model fit indices to predict model fitness. Emotion of love, humor, happiness and excitement in ads were measured through 4 items while 4 items were designed to measure customer buying behavior affected by emotional advertisement .The results of structural equation modelling depicts a good fit. Comparative fit index (CFI) point up a good fit value of 0.82 by meeting the standard value, with adjusted goodness of fit index (AGFI) at 0.81 by being slightly smaller than the threshold of 0.90 , the root mean square error of approximation (RMSEA) is .073 and signifies consistency of our data and a good fit.

The calculated value of CMIN/DFI is 2.07 which shows a good model fit. The values of CFI, RMSEA, specifies that the proposed model was statistically fit as these parameters resultant values meets threshold as explained in the table 9.

Table 10. Regression Weights (Hypothesis Testing)

\begin{tabular}{llllll}
\hline & Estimate & SE & CR & P & \\
\hline Buying Behavior <---Love & .387 & .083 & 4.674 & $* * *$ & H1 Accepted \\
Buying Behavior <---Humor & .323 & .108 & 2.995 & .003 & H2 Accepted \\
Buying Behavior <---Happiness & .224 & .060 & 3.736 & $* * *$ & H3 Accepted \\
Buying Behavior <---Excitement & -.044 & .046 & -.969 & .332 & H4 Rejected \\
\hline
\end{tabular}

The above table illustrate the significant impact of Emotional Advertisement predictors on customer buying behavior for home appliances products. Each independent predictor gives an unstandardized and standardized beta coefficient that predicts the positive or negative impact of each variable. While $p$-value measures significance of data at $95 \%$ confidence interval. Table 10 shows that $\mathrm{H} 1, \mathrm{H} 2$ and $\mathrm{H} 3$ has accepted and supports the research results. Whereas H4 which states that emotion of excitement in ads has a significant impact on customer buying behavior are proved to be rejected. 


\section{Discussions}

The table confirms the dominancy of using love appeal in emotional advertisement which strongly influence customer buying behavior so $\mathrm{H} 1$ is accepted. The images used in such advertisements show a positive relationship between couples or families that inspire the viewers and appear attractive. Khana, P. (2016) found in their study that love appeal used in commercials focuses on a strong relationship between people, showing perfection and enhancement of their emotional bond is likely to influence consumer's buying decision. Such appeals can be depicted in the recent advertisement of Orient home appliances.

Home appliance brands that effectively use humorous appeal in advertisement like Kenwood recent humor advertisement series are able to cultivate positive image of a brand and influence customer for purchase and repurchase. The results also support the narrative thus H2 is also accepted. Weinberger and Gullas (1992) supported emotions of humor used in an advertisement stating that it has a strong impact on viewers driving their interest towards the ad and ultimately the purchase decision. A study conducted by Speck (1987) comparing humorous and non-humorous ads revealed that humor attracts people's attention, induce them to sustain interest, make them to easily get the message content and in the last encourage them to take final action of purchase. Emotional advertisement creates a strong bond between brand and the customer, people directly engage their emotions with brand and feels a sense of association that consequently impact their buying decisions for home appliances products.

Specifically, Home Appliance advertisements that focus on happiness of people and showing sharing happy moments influence customer buying intention. The results support the narrative accepting H3. Bagozzi et al. (1999) stated happiness as one of the major positive emotions that has a favorable impact on the purchase behavior of consumers. Emotions are one of the pertinent factors to describe advertising content (Holbrook \& Batra, 1987), and must use the appeals of happiness to get the consumer response (Mogilner et al., 2012). In the context of home appliances several brands have used happiness as an emotion is advertising to cultivate happy responses on part of consumers. One example is that of Samsung' s commercial depicting usage of different brand products, its features and stylish outlook with a perfect theme of what touches the heart of its consumers. The advertisement blends festive usage with daily family usage of the company`s products. The videography adds up to its fineness capturing it all portraying a happy, loving family in the midst of celebration.

Emotion of excitement and fun also able to create more brand recognition and brand recall which leads to higher loyalty and strong brand relationship. Brands employing excitement or fun appeal in advertisement keeps the people engaged and encourage them to buy the brand to feel something unique. Khanna,P. (2016) opined based on his study on teenagers that the emotions like excitement, and happiness are two prominent emotional indicators that influence the purchase of consumers as it create an impact on the viewer's mind. Excitement appeals have the tendency to highlight brand's functions and enhance message comprehension (Khana, P, 2016). An advertisement similar to this appeal can be supported by Waves home appliance commercial. However, the research results are not supporting H4.

To gain maximum advantage from emotions, emotional advertisement campaigns should be 
strategically and creatively designed. It not only provides a platform to increase sales volume but also play a great role in building brand equity.

After analyzing research results, the regression model developed is as under:

Buying Behavior $=0.387($ Emotion of Love $)+0.323($ Emotion of Humor $)+0.224($ Emotion of Happiness)

Emotion of love, Humor and happiness have strong positive impact on customer buying behavior for Home appliance brands. Whereas emotion of excitement showed a negative impact and rejects alternative hypothesis.

According to the findings, Erevelles (1998) stated that positive moods stimulated by advertising enhances brand attitudes. This outcome is apparently also the case for using suitable appeals. With informational and emotional appeals, on the other hand, to alter the brand attitudes consumers tend to evaluate the advertised brand. The more positive respondents' feel about the advertisement in general, the more attention they pay to it, and more they are persuaded to buy it. Hence, the use of advertisements with a common appeal makes advertisements more persuasive and better liked. The implication is that advertisers should consider carefully the cost of appeals to ensure appropriate return on investment. Marketers must creatively utilize their ideas in advertising appeals used within a commercial to generate positive attitude among viewers which can lead to sell more and more products.

\section{Conclusion}

Advertisements today, has entirely transformed the way marketers promote and sell their products to customer. Due to increasing exposure, the buying decision of customer become more complexed which in turn has increased the need for more creative advertisement appeals. The main focus of this study was to investigate the most influential dimensions of emotional advertisement and to measure their impact on the buying behavior of customer for Home appliances products in Pakistan. Primary data was collected from 200 respondents who are habitual to shop Home appliances products of different brands. The results of the research clearly confirm the positive impact of Emotional advertisement on buying behavior of customer. In modern era, communicating product function and benefits are no longer enough. People want to associate their emotions and feelings with brands which can only be possible by practicing distinct emotional gimmicks in advertisements. Especially love appeal in advertisement strongly influence customer purchase intention and increase brand awareness. Emotions are the magic through which marketers can sell everything. For that reason, many Home appliance brands (i.e. Kenwood, Orient, Waves and Samsung) are adopting emotional cues in advertisements to sell what they want them to sell. The main objective behind this advertisement strategy is to create positive feelings and emotions towards a brand and to reinvigorate or refresh moments to cultivate a strong relationship between Home Appliance brands and their customer that make to purchase more products and endorse.

Today different Home Appliance Brands (especially Kenwood and Orient) employ emotional 
advertisement frequently to surprise and excite their customers. It's also found that Home Appliance Brands using Love, Humor and Happiness appeal in advertisement positively influence customer buying behavior and increase linking and purchasing of their products. Now the marketers of Home Appliance brands should need to learn the significance and importance of using emotion in advertisement to enhance brand recognition, recall and as well as brand loyalty.

\section{Limitations and Suggestions for Future Study}

This study was conducted to assess the impact of emotional advertisement on buying behavior of customer for high involvement products (Home Appliance) in Pakistan. As this study related for academic purpose, therefore we don't have enough time to gather large sample size, and the specified time allow us to incorporate a small size which may slightly differ the findings of the study. Besides only Home appliance products were selected from a high involvement product category to determine the impact of emotional advertisement on buying behavior, which may again limit the results in terms of implications.

For future recommendations, this research should be performed with a large sample size and with context of different industries like eateries and apparel industry. On the other hand, the researcher can employ other response variable besides buying behavior to generalize the results in broader perspective. In specified time, all study requirements were effectively and successfully finalized.

\section{References}

Aaker, D., \& Bruzzone, D. E. (1985). Causes of Irritation in Advertising. Journal of Marketing, 49(2), 47-57.

Aaker, D. A., \& Stayman, D. M. (1992). Implementing the concept of transformational advertising. Psychology \& Marketing, 9(3), 237-253. https://doi.org/10.1002/mar.4220090306

Aaker, D. A., Stayman, D. M., \& Hagerty, M. R. (1986). Warmth in advertising: Measurement, impact and sequence effects. Journal of Consumer Research, 12(4), 365-381. https://doi.org/10.1086/208524

Allen, C. T., Machleit, K. A., \& Kleine, S. S. (March, 1992). A Comparison of Attitude and Emotion as Predictors of Behavior at Diverse Level of Behavior Experience. Journal of Consumer Research, 504. https://doi.org/10.1086/209276

Alvarez, G. A., \& Cavanagh, P. (2004). The capacity of visual short-term memory is set both by visual information load and by number of objects. Psychological Science, 15(2), 106-111. https://doi.org/10.1111/j.0963-7214.2004.01502006.x

Ambler, T., \& Burne, T. (1999). The impact of effect on memory of advertising. Journal of Advertising Research, 39, 25-34.

Ambujakshan, A. (2012). Appealing customers through advertisements: Use of advertising appeal in FMCG products. 
Batra, R., \& Ray, M. L. (1986). Affective acceptance responses of mediating advertising. Journal of Consumer Research, 13(2), 234-249. https://doi.org/10.1086/209063

Büyüköztürk, Ş. (2007). Data Analysis Manual for the Social Sciences: Ankara: PegemA. Publishing.

Byrne, Z. S., \& Cropanzano, R. (2001). The history of organizational justice: The founders speak. Justice in the workplace: From theory to practice, 2, 3-26.

Duncan, C. P., \& Nelson, J. E. (1985). Effects of humor in a radio advertising experiment. Journal of Advertising, 14(2), 33-64. https://doi.org/10.1080/00913367.1985.10672944

Eckler, P., \& Bolls, P. (2011). Spreading the virus: Emotional tone of viral advertising and its effect on forwarding intentions and attitudes. Journal of Interactive Advertising, 11(2), 1-11. https://doi.org/10.1080/15252019.2011.10722180

Edell \& Burke. (1987). The Power of Feelings in Understanding Advertising Effects. Journal of Consumer Research, 14(3), 421-433. https://doi.org/10.1086/209124

Edell, J. A., \& Moore, M. C. (2006). The impact and the memorability of ad-induced feelings: implications for brand equity. In D. Aaker \& A. Biel (Eds.), Brand equity \& Advertising.

Gillet, N., Fouquereau, E., Forest, J., Brunault, P., \& Colombat, P. (2012). The impact of organizational factors on psychological needs and their relations with well-being. Journal of Business and Psychology, 27(4), 437-450. https://doi.org/10.1007/s10869-011-9253-2

Haley, R. I., \& Balidinger. A. L. (2000, November). The ARF Copy Research Validity Project. Journal of Advertising research, 40(6), 114-135. https://doi.org/10.2501/JAR-40-6-114-135

Hansen, J., \& Wänke, W. (2009) Liking what's familiar: the importance of unconscious familiarity in the mereexposure effect. Social Cognition, 27(2), 161-182. https://doi.org/10.1111/j.1083-6101.2006.tb00310.x

Hermeking, M. (2006). Culture and Internet consumption: contributions from cross-cultural marketing and advertising research. Journal of Computer-Mediated Communication, 11, $192-216$.

Holbrook, M. B., \& Batra, R. (1987). Assessing the role of emotions as mediators of consumer response to advertising. Journal of Consumer Research, 14(03), 92-101.

Hongxia, Z., Jin, S., Fang, L., \& John, G. K. (2014). Be rational or be emotional: advertising appeals, service types, and consumer responses. European Journal of Marketing, 48(11/12).

Katke, K. (2007). The Impact of Television Advertising on Child Health \& Family Spending. International Marketing Conference on Marketing \& Society.

Khanna, P. (2016). A Content Analysis of Emotional and Rational Appeals in Selected 
Products Advertising. International Journal of Management \& Social Sciences, 4(3), 568-578. https://doi.org/10.21013/jmss.v4.n3.p7

Kotler, A. (1991). Principles of marketing (pp. 426-427).

Kotler, A. P. A. (2008). Principles of marketing (15th European ed.). Pearson Education.

Kotler, P., \& Keller, K. L. (2008). Marketing Management (13th ed.). Prentice Hall, Upper Saddle, River, New Jersey.

Lacsniak, R. N., \& Muehling, D. D. (1993). Towards a better understanding of the role of advertising message involvement and ad processing. Psychology \& Marketing, 10(4), 301-319. https://doi.org/10.1002/mar.4220100405

Light, M. (1967). An Experimental Study of the Effects of Repeated Persuasive Communication Upon Awareness and Attitudes. unpublished dissertation. Department of Psychology, The Ohio State University, Columbus, OH 4321.

Mattila, A. S. (1999). Do emotional appeals work for services? International Journal of Service Industry Management, 10(03), 292-306. https://doi.org/10.1108/09564239910276890

Michael, L. I. P. (2013). Effective advertising appeals for websites of small boutique hotels. Journal of Research in Interactive Marketing, 7(1), 18-32.

Moore, D. J., \& Harris, W. D. (1996). Affect intensity and the consumer's attitude toward high impact emotional advertising appeals. Journal of Advertising, 25(2), 37-50. https://doi.org/10.1080/00913367.1996.10673498

Niazi, G., Siddiqui, J., Alishah, B., \& Hunjra, A. I. (2012). Effective advertising and its influence on consumer buying behavior.

Nunnally, J. (1978). Psychometric methods. New York: McGraw-Hill

Page, T. J., Thorson, E., \& Heide, M. P. (1990). The memory impact of commercials varying in emotional appeal and product involvement. Emotion in Advertising, 255-268.

Park, C., \& Ethorson. (1990). Influence on emotional response to commercials different executional styles in emotion in advertising: theoretical and practical exploration. In S. Agres, J. A. Edell \& T. M. Dubistsky (Eds), west port: Quorm books (pp. 22-26). Patients.

Poels, K., \& Dewitte, S. (2006). How to capture the heart? Reviewing 20 years of emotion measurement in advertising, 1-47.

Romaniuk, J., \& Sharp, B. (2003). Brand Salience \&Consumer Defection in Subscription Markets. Journal of Marketing Management, 19(3), 25-44. https://doi.org/10.1080/0267257X.2003.9728200

Rossiter, J., \& Bellman, S. (2012). Emotional branding pays off: how brands meet share of requirements through bonding, companionship, and love. Journal of Advertising 
Research, 52(3), 291. https://doi.org/10.2501/JAR-52-3-291-296

Russell, J. T., \& Lane, W. R. (1996). Advertising procedure (13th ed.). USA: Prentice Hall Inc.

Samovar, L. A., Porter, R. A., \& McDaniel, E. R. (2012). Intercultural communication (3rd ed.). Boston.

Saunders, M., Lewis, P., \& Thornhill, A. (2007). Research Methods for Business Students. London: Financial Times Prentice Hall.

Sekaran, U. (2006). Research Methods for Business: A Skill Building Approach (4th ed.). New York: John Wiley and Sons.

Shahid, M., \& Bilal, A (2016). Impact of Emotional Advertisement on Consumer Buying Intention in the Presence of Consumer Emotion Management, 5(1), 43-44.

Shimp, T. A. (1981). Attitude toward the AD as a mediator of consumer brand choice. Journal of Advertising, 10(2), 9-15. https://doi.org/10.1080/00913367.1981.10672756

Sirisagul, K. (2008). Global advertising practices: a comparative study. Journal of Global Marketing, 14(3), 37-41.

Sørensen, J. (2008). Measuring emotions in a consumer decision-making context - approaching or avoiding by approaching or avoiding.

Speck, P. S. (1987). On humor and humor in advertising. Texas Tech University.

Stayman, D. M. (1989). The Incidence of Commercial Types Broadcast in Prime Time 1976-1986. Journal of Advertising Research, 26-33.

Taute, H. A., McQuitty, S., \& Sautter, E. P. (2011). Emotional information management and response to emotional appeals. Journal of Advertising, 40(03), 31-43. https://doi.org/10.2753/JOA0091-3367400303

Taylor, C. R. (2005). Moving international advertising research forward: a new research agenda. Journal of Advertising, 34(1), 7-16. https://doi.org/10.1080/00913367.2005.10639187

Terre Blanche, M., \& Durrheim, K. (1999). Social constructionist methods. Research in practice: Applied methods for the social sciences, 147-172.

Weinberger, M. G., \& Gulas, C. S. (1992). The impact of humor in advertising: A review. Journal of Advertising, 21(4), 35-59. https://doi.org/10.1080/00913367.1992.10673384

William, P. (2000). The Impact of Emotional Advertising Appeals on Consumer Implicit and Explicit Memory: An Accessibility/Diagnosticity Perspective.

Yoo, C., \& MacInnis, D. (2005). The brand attitude formation process of emotional and informational ads. Journal of Business Research, 58(10), 1397-1406. https://doi.org/10.1016/j.jbusres.2005.03.011 


\section{Macrothink}

\section{Copyrights}

Copyright for this article is retained by the author(s), with first publication rights granted to the journal.

This is an open-access article distributed under the terms and conditions of the Creative Commons Attribution license (http://creativecommons.org/licenses/by/4.0/). 